\title{
University Teachers' Perceptions about Assessment Practices: A Study in Five Portuguese Universities.
}

\section{Pereira, Diana ${ }^{a}$ and Flores, Maria Assunção ${ }^{a}$}

${ }^{a}$ Institute of Education, University of Minho, Portugal.

\begin{abstract}
This paper looks at how Portuguese university teachers look at assessment in Higher Education. It focuses on their perspectives about assessment in higher education after the implementation of the Bologna Process, the connection between assessment, teaching and learning process and the selection of criteria and methods of assessment. Data were collected through face-to-face interviews and online open-ended questionnaires in five Portuguese Public Universities in different fields of knowledge. In total, 57 teachers participated in this study. Findings are presented according the categories emerging from the data. Issues of change in assessment practices, the connection between teaching, learning and assessment as well as difficulties to assessing students' work are analysed. Implications of the findings are discussed.
\end{abstract}

Keywords: Bologna Process; assessment; higher education; teachers'perceptions.

Note: This work is funded by FCT - Fundação para a Ciência e a Tecnologia (National Foundation for Science and Technology) within the context of a PhD (SFRH/BD/76175/2011). 


\section{Introduction}

The Bologna Process in Europe has brought about changes in the role of the teacher and the student, in teaching and learning processes and in curriculum and assessment in Higher Education. Within this new framework students are supposed to play a pivotal role in their learning process. The principle underpinning this paradigm shift is, amongst other features, the transition from a system based on the mere transmission of knowledge towards a system based on learning and training, one in which developing both technical and soft skills are of paramount importance (Decree-Law no 107/2008). This paradigm shift implies that "the learning process is not just or primarily about transfer and restitution of knowledge, but about deeper understanding and critical thinking. The implication for learners is that they are not defined as recipients of a service or customers but rather as active participants with shared responsibility for outcomes" (Sursock \& Smidt, 2010, p. 32). This requires more active teaching practices and new forms of assessment which are supposed to be more student-centred (Webber \& Tschepikow, 2013). However, many university teachers face a number of challenges which influence the process of assessment, such as the class size, fewer staff, lack of time, pressures from departments for research and publications (Biggs, 2003), the speed of lectures (Light \& Cox, 2003) and fewer resources with implications for assessment practices. The aim of this study was to analyse Portuguese university teachers' perceptions about the assessment process after the implementation of the Bologna Process. This study also sought to contribute to better understand the reality of the Portuguese higher education contexts, particularly, after the Bologna Process.

\section{Assumptions of assessment after the implementation of the Bologna Process}

In most European countries, changes occurred in teaching, learning and assessment process with the implementation of the Bologna Process (Flores et al., 2015; Pereira et al., 2016). In addition to the Bologna Declaration (1999), the Leuven/Louvain-la-Neuve Communiqué (2009) stresses the promotion of a learner-centred learning approach in order to develop students' competences for the real life. This assumption was further reaffirmed by the Bucharest Communiqué (2012) and Yerevan Communiqué (2015) suggesting the use of a learner-centred approach through innovative methods that promote students' participation and the development of critical skills. However, these changes do not occur in a standard form due to different paces of the Bologna process in European countries (Furlong, 2005; Pereira et al., 2016), leading to "different attitudes and responses of academics" (Sin, 2012, p. 401). In the Portuguese higher education landscape, the paradigm shift begins to be outlined in Decree Law no. 42/2005 which presupposes that "The student should have an active and central role in his/her learning process regarding contact hours, which can take different forms and methods of teaching, or in assessment, which will included all activities 
related to assessment such as contact hours, projects, individual study, field work, etc. Regarding assessment there may be different methods of student assessment such as oral and written essays, examinations, tests, theses, reports on internships, and fieldwork with continuous assessment, etc.". Subsequently, the Decree-Law 107/2008 expresses the obligation of higher education institutions to report the progresses made in relation to the change of the educational paradigm. These changes had led to implications for the assessment process. In this regard The European Association for Quality Assurance in Higher Education (2009) established a set of guidelines emphasising that students should be assessed based on appropriated purposes of formative and summative assessment, through a clear explanation of the assessment methodology, particularly the criteria for marking. The skills' development other than technical skills was also highlighted with the implementation of the Bologna Process. However, earlier literature found that not all of the assessment methods allow the development of such skills (Tuning, 2007). Within this framework a learner-centred assessment emerged as more suitable to meet the Bologna agenda. A learner centred-assessment approach emphasises the student as the centre of the process promoting the active knowledge construction (Webber, 2012). This approach is based on the use of different methods and modes of assessment such as project, portfolio, self-and peer assessment, simulations, amongst others (Flores et al., 2015) which enable the development of skills such as autonomy, collaborative work and critical thinking (Sambell \& McDowell, 1998), promoting feedback and the students' motivation (Huba \& Freed, 2000). Nevertheless, research is needed on changes of educational practices as a result of the Bologna Process (Wihlborg \& Teelken, 2014) and on students' and teachers' perceptions and practices of assessment and learning (Pereira et al., 2016). This study has sought to contribute to understand assessment in higher education, particularly, assessment practices and their relationship with teaching and learning, after the implementation of the so-called Bologna process in the Portuguese context.

\section{Method}

This study aims to answer to the following research questions:

1. Have the university teachers changed their assessment practices after the implementation of the Bologna Process? If so, in which ways?

2. What are the main difficulties they face in the assessment process?

3. How do they relate assessment methods to the teaching and learning process?

4. How do they select criteria and assessment methods? 


\subsection{Participants}

The participants in this study are university teachers teaching year 3 students in 5 Portuguese Public Universities. In total 57 teachers participated in the study; 53\% are male and $47 \%$ are female teachers. Their age ranged between 30 and 68 years old. Most of them (58\%) are Assistant Professors and the years of teaching experience in Higher Education (HE) ranged between 2 and 44 years. Most of them have 29 years of teaching. Out of 57 teachers 32 teach in Social Sciences and Humanities, 10 in Life and Health Sciences, 9 in Natural and Environmental Sciences and 6 in Sciences and Engineering. Out of the 57 teachers 24 were face-to-face interviewed and 33 teachers responded to the questions using the link provided via email. In this study the four scientific fields of research identified at the Portuguese Foundation for Science and Technology were used: Social Sciences and Humanities (SSH), Life and Health Sciences (LHS), Natural and Environmental Sciences (NES) and Sciences and Engineering (SE). Different programmes were selected in each field: SSH: (Educational Sciences, Basic Education, Economics and Law); LHS: (Nursing, Medicine, Pharmacy); NES: (Biology, Geology) and SE: (Mechanical Engineering, Computers Engineering, Biochemistry).

\subsection{Data collection and analysis}

Interviews were conducted with university teachers in five Public Universities. Face to face interviews and responses via email were received in 10 out of the 14 programmes selected. The participants were identified in the different departments in each programme. The interview protocol was designed to obtain data on the following dimensions: changes in assessing student learning after the implementation of the Bologna Process; difficulties associated with assessment in Higher Education (HE), connections between assessment and teaching and learning process and improvements to be made in assessment in HE. The main purpose was to get to know if assessment practices have changed and why. Data were collected between October 2012 and June 2013 in 5 Portuguese Public Universities. Interviews were transcribed verbatim. Content analysis was used to identify emerging categories, enabling a systematic description through the categorisation of data. 


\section{Findings}

Findings are presented according to the emerging categories arising from the data analysis. In this study, the following themes will be explored: perceptions about assessment in $\mathrm{HE}$ as part of the Bologna Process; perceptions on assessment and its connection with teaching and learning process; practices and modes for selecting criteria and methods of assessment; and perceptions and experiences regarding assessment practices.

According to some of the participants' accounts, their assessment practices have changed after the implementation Bologna Process. They claim that they have changed their assessment practices in order to improve the connection between learning and students' future working context, the development of soft skills and the promotion of continuous assessment and feedback in order to better engage students in their learning process. Furthermore, some teachers who have not changed their assessment practices claimed that they have started teaching when the Bologna Process was already in place and others claimed that the programmes in which they taught were already designed according to the assumptions and principles of the Bologna Process.

But most of the participating university teachers coming from the Social Sciences and Humanities state that they have not changed their assessment practices because they already used the so-called learner-centred methods before the Bologna Process had been implemented, which is in sharp contrast to participants' perspectives coming from other areas of knowledge (LHS, NES and SE). They also claimed that they were already concerned with continuous and formative assessment, with the use of practical work inside and outside the classroom, and with systematic and collaborative work from the part of the students. On the other hand, all SE teachers, for example, changed their assessment practices. However, university teachers also state that a number of problems still remain, namely the lack of time to perform all tasks required of them and the top-down imposition to change assessment practices according to Bologna principles. They are sceptical about the effects of the changes in real assessment practice. It is also important to note that difficulties related to the large number of students per class, the shortage in faculty members, the lack of time and availability for teachers to engage in teaching and assessment due to the pressures to engage in more research and to get their work published are also identified by the participants. Issues of fairness and subjectivity inherent to the assessment process also emerged from their accounts. These and other aspects are responsible for the frequent use of more traditional practices rather than innovative and learner-centred methods.

This study also found that the improvements to be made in the assessment process in higher education are similar to the difficulties pointed out by teachers in the assessment process. However, issues related to the connection between the university and the context of work, 
the integration of assessment and learning, plagiarism and lack of maturity of the students were also aspects in need of improvement in the assessment process in HE. Findings from the study suggest that participants recognise that the assessment methods they put into practice strongly influence the teaching and learning process. In particular, they highlight the promotion (or lack of it) of students' participation and engagement in the activities in the classroom, the emphasis on the outcomes and the lack of valorisation of formative assessment and the role of feedback. In other words, students' participation and perceptions about assessment influence their engagement in the learning process.

Furthermore, assessment also influenced the teaching process. Participants of this study claim that they had to change their teaching practices according to assessment methods used. One of the reasons identified by the teachers is the need to adapt teaching methods to the students' choices of the assessment practices. However, teachers refer that there was no negotiation of assessment methodology with the students. Findungs also show that the adequacy and content mastery are clearly the criteria most valued by the teachers. The attendance and participation in classes and the development of soft skills such as communication skills, critical skills and writing skills were also identified by the teachers. The setting up of criteria is related to the assessment methods used, and consequently there are skills that only can be developed using given assessment methods. Not all of the assessment methods enable the development of soft skills such as learning to think, work collaboratively, communication skills and critical thinking. The participants claim that when students perform a test what is most valued is the scientific knowledge; however when assessed by other assessment methods, such as practical reports, in addition to scientific knowledge, writing and group work skills are also valued. Also, it was found that teachers selected the assessment methods and the criteria based on learning goals, and the characteristics and learning outcomes of the programmes. This may indicate that the curricular design of each programme may influence the assessment methods to be used and the selected criteria. Therefore, curriculum design may guide, albeit not explicitly, teachers' actions regarding the choices of methods and assessment criteria. Teachers emphasise the importance of assessment in integrating both technical skills and soft skills, as these enable the connection with reality and the future professional life. The kinds of assessment that can stimulate students to apply knowledge in contexts and real situations is framed with a learner-centred assessment perspective. In teachers' view, assessment methods such as practical work, problem solving and projects along with continuous assessment are best suited to this purpose. Teachers claim they use self and peer assessment as these modes of assessment have advantages such as: promoting autonomy, critical thinking, self-regulated learning, fairness, enabling the students to recognise their successes and failures and those of their colleagues. They also recognise that these methods support the students in the assessment process. However, some disadvantages were also highlighted by participants such as: subjectivity, unfairness and the fact that the students were not coherent when 
giving grades to themselves and to their colleagues. Thus, issues such as peer and selfassessment need further attention as well as the nature and form of feedback ti be used by both the teacher and the students.

\section{Conclusion}

Findings from this study point to some conclusions. First, although teachers claim that there have been changes in assessment practices after the Bologna Process in their accounts it is possible to perceive that the practices they consider to be the most suitable to the Bologna principles are not those sometimes those they actually use. This is due to lack of conditions and a number of constraints that currently exist in higher education with regard to the assessment process, such as large classes, the semester structure, the organisation of working time and lack of availability of teachers for pedagogical issues. Teachers appreciate the characteristics of an assessment centred on the learner, as it allows the development of key skills for the professional world. However, the difficulties in assessing do not allow them to use these methods as they would like to. The same happens concerning continuous assessment through feedback. Even when the changes in the assessment practices are imposed by some universities, teachers are reluctant to use them because of these constraints. So, improvements are required by the participants in the assessment process in higher education in order to allow the use of assessment practices that they consider more appropriate to improve learning and more suitable to higher education purposes. Consequently, there are some tensions between what they want to do and what they can do in in the light of the conditions that they face. This study also suggests that assessment influences the teaching and learning process. Through assessment, or depending on the assessment method used, learning and teaching is developed in different ways. Motivation and students' performance, self-regulation of learning and the nature of the skills to be developed are related to the assessment methods used. More needs to be done in this field, particularly in regard to students' and teachers' perceptions of assessment after the implementation of the Bologna Process in different European countries and research on the effectiveness of the learner-centred methods in terms of student learning in different fields of knowledge. 


\section{References}

Biggs, J. (2003). Teaching for Quality Learning at University. Buckingham: SHRE and Open University Press.

Bologna Declaration. (1999). Joint Declaration of the European Ministers of Education. Bologna: The European Higher Education Area.

Bucharest Communiqué. (2012). Making the Most of Our Potential: Consolidating the European Higher Education Area.

Decree-Law no 42/2005. (2005). Ministry of Science, Innovation and Higher Education. Portugal.

Decree-Law n ${ }^{\circ}$ 107/2008. (2008). Ministry of Science, Technology and Higher Education. Portugal.

European Association for Quality Assurance in Higher Education. (2009). Standards and Guidelines for Quality Assurance in the European Higher Education Area. 3rd ed. Helsinki: ENQA. Retrieved from http://www.enqa.eu/wpcontent/uploads/2013/06/ESG_3edition-2.pdf.

Flores, M., Veiga Simão, M., Barros, A., \& Pereira, D. (2015). Perceptions of effectiveness, fairness and feedback of assessment methods: a study in higher education. Studies in Higher Education, 40 (9), 1523-1534.

Furlong, P. (2005). British Higher Education and the Bologna Process: An Interim Assessment. Politics, 25 (1), 53-61.

Huba, M.E., \& Freed, J. (2000). Learner-centered Assessment on College Campuses: Shifting the Focus from Teaching to Learning. Boston, MA: Allyn and Bacon.

Leuven/Louvain-la-Neuve Communiqué. (2009). The European Higher Education Area in the new decade. Communiqué of the Conference of European Ministers Responsible for Higher Education.

Light, G., \& Cox, R. (2003). Learning \& Teaching in Higher Education: The Reflective Professional. London: Sage Publications.

Pereira, D., Flores, M., \& Niklasson, L. (2016). Assessment revisited: a review of research in Assessment and Evaluation in Higher Education. Assessment \& Evaluation in Higher Education 41 (7), 1008-1032.

Sambell, K., \& McDowell, L. (1998). The construction of the hidden curriculum: messages and meanings in the assessment of student learning. Assessment and Evaluation in Higher Education, 23 (4), 391-402.

Sin, C. (2012). Academic Understandings of and Responses to Bologna: a three-country perspective. European Journal of Education, 47 (3), 392-404.

Sursock, A., \& Smidt, H. (2010). Trends 2010: A decade of change in European Higher Education. Belgium: EUA Publications.

Tuning. (2007). Tuning Project Report: General Brochure final version J. González \& R. Wagenaar (Eds.),Retrieved from http://www.unideusto.org/tuningeu/images/stories/documents/General_Brochure_final_ versio n.p df. 
Webber, K. (2012). The Use of Learner-Centered Assessment in US Colleges and Universities. Research in Higher Education, 53 (2), 201-228.

Webber, K., \& Tschepikow, K. (2013). The role of learner-centred assessment in postsecondary organisational change. Assessment in Education: Principles, Policy \& Practice, 20 (2), 187-204.

Wihlborg, M., \& Teelken, C. (2014). Striving for Uniformity, Hoping for Innovation and Diversification: a critical review concerning the Bologna Process - providing an overview and reflecting on the criticism. Policy Futures in Education, 12 (8), 10841100.

Yerevan Communiqué. (2015). Communiqué of the meeting of European Ministers in charge of Higher Education. 